\title{
Christian Values and Indian Classical Dance
}

\author{
by Francis Barboza
}

Down through the centuries man has used various means and mediums to communicate and express himself to God and to his fellow men. Anthropologists tell us that every group of people that has lived in India has been restless and explosive in expression. Early conquerors and missionaries from the west found dancing wherever they went, but paid very little attention to it. This is to be regretted because India has much to teach them in the domain of the fine arts, especially music, dance, painting and sculpture which are always a means of communicating one's inner experience to God and man. The races shared little except fire-water, gun-powder and guns, a wretched basis for any cultural exchange. Christians in India by and large failed to use Indian dance in their religious and liturgical life, due largely to the unsympathetic and hostile attitude of the western Church.

In this brief essay, efforts have been made to analyse dance as a medium of expression and communication. A short historical survey is also provided to show how dance and religion are intimately connected. Then, briefly, the problem of the Church is disincarnation. Later we will see for ourselves that Christianity is something which is in harmony with dancing, and that Indian dance, with meaningful changes and interpretations according to time and place, can express and preach the mystery of Christ.

\section{Dance as a Medium of Expression and Communication}

All of us love to tell or express what is in our hearts. But most of us just manage to communicate what we really mean at only three or four peak moments in our lifetime, and then, perhaps, only to a few friends. All works of art, especially Indian classical dance, are a medium through which men communicate what lies beyond ordinary speech. Many people think of art as something special and apart from their daily lives, a luxury, an occupation or hobby for impractical individuals. This is a mistake. Man cannot live without art because deep down in us there is a thirst for creative expression. While God expresses himself in nature, man expresses himself through creative arts. In the same way, man appreciates and admires this creative art in another, for artists speak in the language of beauty. In every human heart there is the love of beauty in some measure. That is why music, drama, dance and poetry stir the hearts of all and elevate the human spirit. What cannot be conveyed by ordinary means is expressed in the language of art. If men are not able to communicate they die of loneliness. Dance, as we shall see, is communication at the deepest and most lasting level, where the dancer tries to reach out to all by the use of symbols.

In Indian dance we use not merely signs but symbols. A sign works as a cause and effect in the communication process and in giving information. It is exhausted and empty as soon as the message is transmitted. Moreover, it is an outward process and knowledge. It is also artificial and conventional, whereas a symbol is incarnate in the human being. For example, I have used the symbol (Hasta) for the Holy Spirit. The

P. Francis Barboza, svd (31), studiert und tanzt klassischen indischen Tanz an der Universität Baroda (Indien). 
left hand is held close to the heart as in the Tripathaka hasta (a flag with three fingers) to denote a burning lamp or a rising flame, and the right hand is held in the Hamsasya hasta symbol (a swan's beak) denoting sacredness and blessing. Now whenever the above mentioned hasta is seen in a dance, the audience encounters the person of the Holy Spirit ${ }^{1}$.

Thus the symbol reassembles elements which have become separated from one another, and points to something which is not present. Here the symbol of the Holy Spirit gives the dancer the sense of being a sanctifier. He feels the presence and the person of the Holy Spirit in him. As Ted Shawn says, dance is an „expression plus creation ... and when man has the sense of being a creator, he shares in the function of the Godhead" 2 . The audience also undergoes a similar process depending on each one's personal experience of the Holy Spirit and his ability to appreciate the symbol and the particular sentiment (rasa).

Thus the symbol never becomes exhausted and empty. Here there is an inward process of communication where we enter into an experience and become one with the symbol. Our experience also depends on our personal disposition and how much we are able to assimilate and become ohne with the art form.

We have seen that the activity of dance is communication plus creation. Now, the question is, what exactly do we communicate? Many distinguished thinkers have attempted different answers. Aristotle said that it is "an imitation of emotions". Tolstoi called it "a manifestation of feelings" but the definition most acceptable to me is that of Ouspenski, who said that "art is a communication of ecstacy". Dance is a communication and an expression of one's feelings, emotions, experience and ecstacy, and is a message to others. "People working in art (dance) must vibrate on a higher level, but this faculty fails to become an art unless the person can communicate its vibration to his audience so that they share it with him"3.

The ability to convey or reproduce emotions gives power. It is a tremendous gift, mysterious and precious. Men value emotion; it is one of the chief wellsprings of human activity, but it is perishable. It lasts only for a short while and it can affect people while it is strong. Therefore an artist, especially a dancer, tries to fix it in forms that will endure and that will arouse a response in many people at widely different times.

The elements that account for the proper communication of the dancer's ecstacy, feeling, experience and message through dance to others are mainly space, time and the human body. Dancing is an arrangement of pattern in space as is architecture and painting. It is also an arrangement in time, and employs time-rhythm as does music. The speciality of dance is that it uses rhythm in both spheres, audible and visual. Music and poetry exist in time; painting and architecture exist in space; but dance lives both in time and space. The greatest medium of communication is the human body which has to be trained in dance technique both to obey the commands of the mind and mirror the emotions. The dancer lives the message and communicates it simultaneously.

Dancing moves us. It excites us. It compels and persuades us. It reveals to us aspects of life and human emotions. This is because we are in close physical sympathy with what we are looking at. The free movements of the dancer keep our body at ease, and difficult movements contract and tense our muscles and tighten our nerves. 
Rhythm sets our blood racing and our feet tapping in unison. In dancing, emotions are transmitted also through the pattern of steps. It is the pattern that moves us in spite of our unfamiliarity with the subject or the performer, and involves us emotionally with the artist and his intent.

Dance uses distortion. This is generally the stretching of tendons and joints beyond what is comfortable and easy. In religious dances, endurance becomes a kind of distortion. The very fact that a dancer has surmounted a real physical difficulty is a proof that he can do things which an ordinary man cannot. This gives him power, the power of expression and communication without the spoken language and familiarity with his listeners.

In India many forms of classical dance have come into existence in the course of time. A classic, in any art, is a work which after long testing has proved to be unfailingly effective. Art forms are transmitted from generation to generation by society, just as language or skills or behaviour are transmitted by society.

The language of dance is superior to all spoken languages and transcends the barriers of any particular human society. McNeill Dixon, who gave the Gifford lectures at the University of Glasgow during 1935-37 said "The dance is a vernacular, a dialect of the soul." So dance comprises the whole humanity. It consists mainly of three types of movements: instinctive actions and expressions, sign language, and dance steps.

Instinctive actions: On certain levels all men move alike. They walk alike, they run alike, crouch, jump, strike to kill, cower in fear, laugh or sneer, stretch out their hand in pity and love. These expressions of emotions are common to all men and are recognised by all. They are largely physiological. And many of man's basic movements are akin to the animal's and to the rhythm found in the universe.

Thus everyone, even little children, can instantly recognise dislike, anger or fear. Love and affection and kindness are also instantly recognised as though man had a sixth sense, but it is really the recognition of small signals.

Sign language: Beyond this instinctive, physical expressions common to nearly all men at all times there are acquired idiomatic gestures differing with cultural groups, and although similar and extending over periods and territories, they are neither instinctive nor universal. The relation to dancing lies in their prevalance and endurance.

There are certain similar gestures in all parts of the world, such as nodding or shaking one's head, extending the right hand in friendship, uncovering the head as a mark of respect. But a certain degree of difference in sign language cannot be ruled out, owing to geographical and cultural background.

Dance steps: Like sign language and instinctive action, dance steps also help in communicating to the audience the mood and message intended by the dancer. If dance is to arouse forceful feelings of dread in the audience, then the steps have to be quick and rough in both visible and audible rhythm. If it is to arouse and communicate a soft and fine feeling to the audience, then the dancer's footwork has to be slow and soft in both visible and audible rhythm. Thus appropriate and fitting steps for a particular dance will help in its effective and meaningful communication. 
In this short analysis, we have seen that dance by itself breaks down all the distinctions and isolations of the body and soul as separate compartments. It also breaks down all the distinctions that society has established. Dance is primarily meant to express and communicate one's feelings, emotions and inner experiences to one's fellowmen. It is not restricted to any particular caste, creed, society, religion or place, or laws laid down by the society. It is an expression because the dancer expresses his innermost experiences and emotions. It is a creation because the dancer, to express his inner experiences, creates different forms and images. Thus, the incarnation of his inner experience takes place simultaneously in time and space. Forms come into existence and disappear.

But the purpose of dance (communication and expression) is served because the experience of the dancer and his message are transmitted to his fellowmen and they in turn make them their own, each according to his powers of receptivity. So we can say that dance, in itself, has been and is one of the best media of expression and communication, perhaps the very best.

\section{Religion and Dance in India}

In India, dance clearly has divine origin. Bharatas Natya Shastra (in his treatise on Indian Dance) explains the origins of this divine art: "When the world had become steeped in greed and desire", he tells us, "in jealousy and anger, in pleasure and pain, Brahma, the Supreme One, was asked by the people to create an amusement which could be seen and heard by all, for the scriptures, being learned and ambiguous, were not enjoyed by the masses."4 Brahma, the Supreme One, the knower of truth, meditated on the four Vedas (Scriptures) and drew up a fifth, Natya Veda, the scripture of drama, presenting moral and spiritual truth. And thus he said to the people: "This art is not purely for your pleasure but exhibits bhava (emotion) for all the three worlds. I have made this art following the movements of the world, whether in work or in profit, peace, laughter, battle or slaughter, yielding the fruit of righteousness to those who follow moral law, a restraint for the unruly, a discipline for the followers of a rule, to create wisdom in the ignorant, learning in scholars, affording sport to kings and endurance to the sorrow-stricken, replete with divers moods, informed with the varying passions of the soul, linked to the deeds of all mankind, the best, the average and the low, affording excellent counsel, pastime ${ }_{2}$ and all else."

Another treatise, still used by dancers today, is a book called Abhinaya Darpana (Mirror of Gestures) by Nandikeshwara which deals in great detail with Angikaabhinaya, by which the dancer studies each movement of the head, eyes, mouth, neck, hands and the whole body. What were once the "mudras" used by the priest in prayer became a whole language for the dancer known as "hastas", the symbols of the hands.

In all important literature of India, dance holds a prominent place. The two great epics, Ramayana and Mahabharatha, are full of references to the religious significance of dance. There are several other "puranas" such as Koyil puranam, Unmai Vilakkam, Titu-Arul Paya, etc. which speak of the use, meaning and purpose of spiritual identification and perfection. In the Vedic period people used dance for religious, social and ritual purposes, for example during the horse sacrifice, wedding and many other important rituals. During Buddhist, Gupta and the medieval 
periods, dance had an important role in achieving the spiritual inspiration and identification of the people of that time. The existing temple sculptures, paintings and icons are a compelling proof shedding light on the past. Later, with the invasion of the Muslims who considered it almost a scandal to use music and dance for divine worship, dance was brought to the courts for entertainment. It is also due to the apathy of people with regard to their religion that many in society used dance for erotic pleasure. Thus, with the Muslim rule, there came into existence a new caste of people called "Naachi-wali". When Europeans, for whom dance was a mere social function, came to India, the process of degeneration in dance continued. With these developments, the aim, purpose and goal of dance apparently changed. It could be likened to a diamond which had lost its lustre. But by the middle of the twentieth century a period of revival in Indian dance took place, thanks to dedicated people like Rukmani Devi, Krishna Iyer and others who laboured to restore the apparently lost dignity and spiritual sanctity of this divine art.

Although today the Indian classical dance has moved from the temple to the auditorium and stage, the dedication of its performers remains the same.

"Art emerges from the womb of religion and from the mystery of magic." 5 This is very true in India, where religion and philosophy are preached and God worshipped through dance forms. "The Indian mind has always sublimated the fine arts from their mundane origin to the highest level of social and cultural life, inextricably interweaving them with religion." 6 That is why "Art in ancient India could perhaps be called temple art, not because it was necessarily a part of the temple, but because its aim was the perfection of spiritual identification"? In India the temple has been a place of communication between God and man. Different arts have sprung up from the temples and God was worshipped in music and dance. The driving thirst of man for union with the Almighty led him to establish "in every temple a Natya sabha or rangamantapa, where music and dance performances took place as part of religious ritual"8.

Dancing was considered to be the highest form of worship. Vishnudharmottara Puranam tells us that "to worship God by nritta (dance) is to fulfill all desire, and to him who dances the paths of salvation are unfolded. The dancer, as he undergoes the mystical experiences in the dance, communicates the same to the audience. In other words, dance becomes the expression of the experience of revelation and complete union with God. Thus, "dance and all other fine arts have not only a utilitarian function but also a spiritual and cultural function in India"9.

\section{Dance in the Church}

In the Old Testament, dance was not only part of profane celebration but was also used for sacred functions. Dance was part of Yaweh's victory over Egypt (ex. 15-20), the procession in which David brought the Ark of the Covenant into Jerusalem ( $2 \mathrm{~S}$ 6:5 ff) and the celebration of the Golden Calf(Ex. 32:19, also Ps. 150:4, 149:3). Jeremiah sees maidens dancing in the joy of the messianic Israel (Jr. 31:31). The dance which David performed before the Ark is described by a word not occurring elsewhere; it must have been unusually vigorous, to judge by the criticism made by Michel (2 S. 6:14), 16-20). The conduct of Saul with the prophets (1 S. 10:10 ff; 19:20 ff) suggests that the companies called Sons of the Prophets conducted a cultic worship of songs and dance. Even in the New Testament we find references to dance 
when Jesus speaks of children singing and dancing in the street (Mt. 11:17 ff; Lk. 7:32). Thus it is a clear sign that religious dance was a regular form of ritual and worship and very much integrated into the life of the people.

Curt Sachs in his book "World History of Dance" quotes a Gnostic hymn of the second century and makes use of it in one of his chapters. Many of the hymns of this early date were evidently works which accompanied dance rituals in the Christian Church, and were dramatic and symbolic. Sachs tells us in this connection that there is a apocryphal saying of Jesus, "Whosoever dances not, knows not the way of life." He then gives an interesting quotation, "Whosoever knoweth the power of the dance knoweth the power of God." In Egypt, when the organised Church had reached a high level of culture and when the priests were allpowerful, dance was the chief medium of religious expression. We also have records that during the Periclean age when culture had reached its highest level, dance was used for religious purposes. Plato wrote, "To sing and dance well is to be well educated". In the early Christian Church dancing was accepted as a normal and suitable means of worship and praise of the Lord. Speaking of the existence and use of dance in the early Church, Ted Shawn says: "I engaged in a research to pile up evidence that in those first vital centuries when our own Christian religion was fresh and undegenerate, the dance was used as the chief expression of ritual and worship." ${ }^{10}$ In some cases religious ballets survived to the 20th century, the most notable being the "Baile de los Seises" of Spain.

Ancient Rome not only borrowed dance, but also cheapened it by unbridled licentiousness and sensuality. During the Dark Ages when false asceticism gained power in the Church, dance was eliminated from its life and worship. Today most Christians are prejudiced against this medium of expression, but it is important to bring back to people the idea that dance is not something alien to our religion, and that our faith can be better expressed in dance form than in any other medium. The fact that this particular art form has been misused cannot be a valid argument for its total elimination.

Disincarnation is the problem of the Church. In this present age man's feelings and perceptions are clouded over by the development of technology, by rationalism and ideologies. He is no longer able freely to experience reality. His body and senses play only a minor role in his understanding and perception. This development has caused social and psychological problems, and is also the root of some religious difficulties. It is hard for man to encounter God in his personal and religious life. This state, which I call the disincarnation of man, has greatly affected the Christian Church. Christian theologians, including the liturgists, have shown greater inclination and affiliation towards the philosophers, expecially the metaphysicians. In the process they have almost lost touch with poets, artists, dancers, dramatists, musicians. In particular, prominence has been given to idealists, rationalists, romantics, and men of large generalisation and abstraction.

The direct result of the development is seen in the overemphasis of moral and religious doctrine and dogma, as opposed to the expression of religious feelings and faith. It is odd that a religion which is centred on incarnation ("The Word was made flesh") should tend towards philosophy and abstractions. One would surely expect it to tend towards art with special sensitivity, expecially to dance, music and painting. To a great extent the Church had used art for decorative and recreational purposes 
rather than to express man's belief, his situation and life. Most of us forget that it is the arts which give dynamism and spontaneity to our faith.

\section{The message of Christ through Indian dance}

Recalling his experience as a religious dancer, Ted Shawn says, "By dancing the twenty-third psalm and working out other Biblical subjects along this line, I presented in 1917 a composite Church service in dance form at the First Interdenominational Church in San Francisco, with the Rev. Dr. Henry Frank lecturing on the relationship between the dance and religion, and every person in a crowded congregation saw the fitness of expressing religion through dance. This was the first time anything of this kind had been done, and it is noteworthy that the newspapers treated this startling innovation seriously and with dignity." 11 Commenting along this line the Pastoral Instruction on the Means of Social Communication points out that the "artistic expression both for its own excellence and for what it does for man should be highly appreciated. Of itself, beauty ennobles the mind that contemplates it. The work of the artist can also penetrate and illumine the deepest recesses of the human spirit. It can make spiritual reality immediate by expressing it in a way that the senses can comprehend. And as a result of this expression man comes to know himself better. This is not only a cultural benefit but a moral and religious one as well." 12

In India the theatre with its artistic expressions is the most ancient yet the most lively and forceful means of human expression and communication. It is true even today that it evokes a tremendous response from people. As I have already pointed out, it was a mistake of omission by missionaries and the Church at large not to have made use of such an excellent medium as Indian classical dance in worship and preaching the word of God.

"Let them praise His name in the dance" (Ps. 149:3). It is interesting to note that dance is mentioned favourable at least seventeen times in the Bible, and not once with disfavour. "For there is no reason at all why we should not praise our God with rhythmical movements as well as with our tongues and vocal chords, for surely no particular preference is given in the Scriptures to these particular organs. The body is the temple of God and therefore, when you praise your God, you should do it with your whole being, for if you really feel religion it means an entering into ecstacy, and that means movement." 13 By body I mean the whole man where God continues to reveal himself. Dance is the medium of expression of the inner experience of revelation. The worship which is offered by man, the temple of the Holy Spirit, will be the highest praise and worship to God and the best form of expression of the revelation of God in man. Nietzsche said, "and now there dances a God in me; if one is moved by a divine feeling one is moved by the rhythm".

Dance is a sacred, and therefore a liturgical sign. The dancer alerts and informs or communicates a message to the community. In a true religious dance he also reveals his communion with God and enables the audience or the participants to have the same union with the Allmighty. Thus, in the Christian context, it becomes the expression of true charity where the dancer shares his mystical and revealed experience with the community.

Dancing is also a liturgical and ritual action. Certain rituals can be better expressed through the form of dance. Understood in the context, dance helps us to a richer and 
continuous re-enactment of salvation history in a most effective way, because people not only hear the word of God but also are able to see it and experience it for themselves. Dance, with its many forms and rhythms. has a greater impact than mere abstractions.

There is a close affinity between the priest in the sacrifice of the mass and the religious dancer. The priest offers sacrifices and prayers with the people to God, and preaches the word of God to the people. The dancer offers himself and enables the people to offer themselves to God and receive the joys of union with the Allmighty. It is the merit of mankind to reach beyond the visible reality through artistic forms. Thus in a true religious dance the message of Christ can be preached effectively and an authentic religious experience can be achieved.

Like the incarnation, death and resurrection of Christ, dance is also a "kenosis", a self-emptying or giving of oneself in love. A dancer gives himself, his most personal experience and visions to others through the medium of his artistic object or form. Its essential quality is also "koinonia", sharing with the community which is the very basic principle of Christian life. Here the dancer shares his personal feelings, his insights and experience, and life itself.

\section{Difficulties involved in this new venture}

The nature of the impediments is varied. First and foremost I would point out that there are countless prejudices against the use of Indian dance in our religious and liturgical life, especially in the minds of traditional Christians. Many Christians still carry on the Western frame of mind though they live in India. (The reasons are obvious). For a European dance is mainly a social activity, an entertainment, whereas in India classical dance is mainly a religious activity and its aim is spiritual experience.

The majority of the Indian Christians do not have sufficient insight into Indian culture and fail to see the difference between the Indian culture and Hindu religion. Well, the distinction is delicate, yet can be traced. For example, the theme of Indian classical dance is always from the Hindu religion; yet one can find a highly developed and sophisticated technique in each dance school independently of the theme.

In the use of the hastas there are only a few which are used exclusively for each particular Hindu god or goddess. At the same time we have many hastas which are for common use. Now, when I want to use a particular hasta for any personality of the Bible I will have to invent them with the theological background and the knowledge of the Hasta-language. Thus, to develop a truly Christian tradition one has to create new forms using the existing technique and of course the theme has to be taken from the Bible. It is hard, yet it is worth the pains.

\section{Attempts to use classical dance}

As far as I know there are very few attempts made by the Church in this line. "The Madras Christian Association" has been putting up dance-dramas successfully using at times Bharata Natyam and other classical dance techniques. Fr. Proksch, SVD, has done a lot in the line of music and dance. He has mainly used folk-styles in his dance-ballets very successfully. 
It is very interesting to note that recently some learned Hindus from South Kanara joined together and presented Christ's life under the title "Mahachetana: Christa Mahatme", written by the poet Muliya Keshavayya, in the classical dance-drama called "Yakshagana". But they did not get enough appreciation from the Christians and the Church authorities. So, it has not really spread as one would wish.

I myself seem to be the first Christian to present full Bharata Natyam dance recit $\varepsilon$ on Christian themes. One would like to propose that in each classical dance school at least one Christian is specialized and is able to give full-performances using Christian themes. The Church in India has invested in many things but has done practically very little in the life of the culture of the country ${ }^{14}$.

Indian classical dance was born and nurtured in the temple, and its theme has always been religion. It has been used both for preaching and worship. "This ancient interest in the theatre should be maintained by Christians today and full use be made of its possibilities. Playwrights should be encouraged and helped to set man's religious preoccupation on the public stage. This is often the first step in a much wider diffusion made possible by the communications media." 15 With my experience in classical dance and the experiment conducted to present the Word of God through Bharata Natyam, I can say that this media is very effective and captivating. All the same, when we use dance for liturgical and religious purposes we should not forget that it is meant to help us towards a fuller understanding and worship of the Word. Thus it should not be only be artistic but also holy, functional, bearing the signs of salvation. Indian classical dance can play a major role in assimilating, preaching and understanding Christ and the key words of the Gospel, "And the Word became flesh and dwelt among us, full of grace and truth" (John 1:14).

\section{References}

1 With my theological background and the studies made on the Indian dance treatises I have invented and used different gestures (hastas) for many personalities of the Bible in my production "Something Beautiful for God", a Bharata Natyam recital based on Christian theme.

2 Ted Shwan, Dance we must, Pub. Dennis Dobson Ltd., London 1946, page 2.

3 Ibid, page 10.

4 Origin of Dance: Natya Shastra by Bharata Muni Ch. I: 1-23.

5 R. Sathyanarayana, Studies on Indian Dance, Pub. Sri Varalakshmi Academies of Fine Arts, Mysore, 1970, page 89.

6 Ibid, page 7.

7 Mrinalini Sarabai, Understanding Bharata Natyam, Maharaja S. University of Baroda, 1975, page 17.

8 Ibid, page 20.

There are many schools of classical dances in India. To name a few: Bharata Natyam, Kathkali, Kochupudi, Odissi, Manipuri, Mohiniattam, Chau Yakshagana, etc. Beside these we have countless folk and tribal dances peculiar to each region and tribe. Among the classical dances we have a few which are wellknown and others are still confined to a small region where it originated, grew and developed. 


\section{Bharata Natyam}

This classical dance is practiced in South India, Tamil Nadu under the name of Bharata Natyam and the centres where it is most common and active are Tanjore and Madras. And today it is the most popular classical dance in India and abroad. It has a highly sophisticated technique and most moving divine themes on which it is based. Countless dance poses of this school can be found in the temple sculp ture of the South. Incidentally I am specializing in this school of dance.

\section{Kathak}

This classical dance is practiced in North India. The word Kathak literally means "story teller" referring probably to the old bards and story narrators who used to travel over the country entertaining the people with sacred legend folklore and mythology as part of the cultural programme. This very old form of entertainment later incorporated music, dance and mime and became a disctinct dance form. The theme is based mainly on Krishna, one of Vishnus avataras. Of course other gods and goddesses are also included. It has a very powerful footwork and whirling movements.

\section{Katbakali}

This school of classical dance which is mainly performed in Kerala, South-West India, is presented in dance drama form. Kathakali actually means "Story play". It has a long history and development which has led to the present form. It has very peculiar make-up and costume. The themes are mainly taken from Mahabharata and Ramayana and other Puranas. The idea is the victory of the good over evil. Originally danced only by men.

Odissi

This classical dance is practiced in Orissa, a state on the mid-North-Eastern coast of India. The centres are Puri and Bhuvaneshwar. It has a highly developed technique and style of its own. The dance is full of slow movements and at the same time very graceful. It is full of devotional themes. The main deity is Jagannath (Lord of the Universe). Since a few years this school is picking up its popularity.

\section{Kocbupudi}

This classical dance is practiced in Andhra Pradesh, a state on the mid-Eastern coast of India. The name, Kochupudi comes from the village where it originated. It is also a dance drama form where at times dialogue is also used. The theme is of course Shiva Puranam, Ramayana, Mahabharata, etc. Till recently only men used to dance. Now even ladies take the female role.

Thus, all classical dances of above and others have the theme either religion or philosophical truth. One can very well see that all the classical dance schools follow Natya Shastra, a treatise on dance, drama and music. At the same time each style has its peculiarity of its own due to the regional influence.

Folk Dances

Unlike the classical dances all the folk dances of India are quite spontaneous and are the creation of people's imagination and desire for artistic and emotional expression. They are not rigid in their expression. The whole depiction of folk art is guided by the songs that either glorify nature, express traditional occupation or offer devotion to the deities. Each folk dance being unique to its region includes warmth of expression and a charm and beauty that are refreshing by their very untutored quality. The number of folk dances in India is legion.

\section{Tribal Dances}

Like the folk dances, the tribal dances in India are full of the same spontaneous freedom and natural grace. They are also seasonal and religious. Nature is always the strongest inspiration for all of them, coupled with custom, and a religious heritage that has much in common. 
9 R. Sathyanarayana, Studies on Indian Dance, Pub. Sri Varalakshmi Academies of Fine Arts, Mysore 1970, page 7.

10 Ted Shawn, Dance we must, ... page 32.

11 Ibid, page 33.

12 Pastoral Instruction "Communio et Progressio" on the means of social communication written by order of the Second Vatican Council, Rome 1971, No. 55.

13 Ted Shawn, Dance we must, ... page 34.

14 One of my dreams would come true if the Church institutes a few scholarships to the deserving Christian students who wish to specialize in dance and music.

Examples of Christian hand gestures (Hastas)

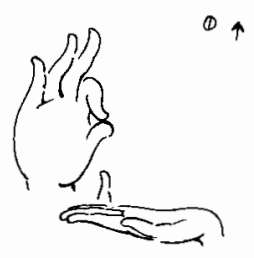

1. Holy Spirit: The right hand shows the coming of the Spirit.

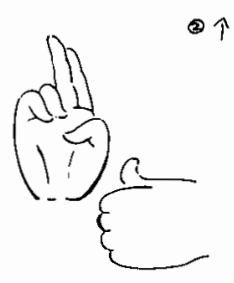

2. Risen Christ: The right hand symbolises the Second Person of the Trinity, Christ, and the left hand indicates victory (Right hand $=$ Ardapakaka. Left hand $=$ S'Ikara. $)$.

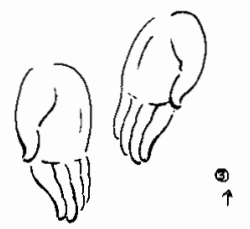

3. Mary: Both hands held in Pataka, downwards, the left on the womb and the right held even lower, symbolising one who gives and always helps - the helping hands of the mother.

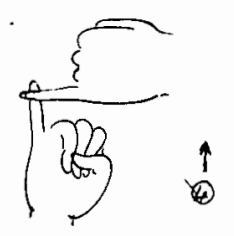

4. The Cross: In order to show the Cross in the most symbolic way the small fingers are used to denote the Cross. 


\section{ZUSAMMENFASSUNG}

Jedes Kunstwerk, vor allem aber der klassische indische Tanz, ist der Versuch, etwas vom menschlichen Erleben auszudrücken, was über die alltägliche Sprache hinausgeht.

Dabei empfinden viele Menschen Kunst als etwas, das jenseits ihres alltäglichen Lebens liegt, als nutzlosen Luxus oder ein Hobby. In Wirklichkeit aber kann der Mensch nicht leben, ohne die schöpferische Sehnsucht seines Herzens zu erfüllen. Die innere Sprache der Kunst braucht Ausdrucksformen, die über die gewöhnliche Sprache hinausgehen. Der Tanz ist dabei die tiefste und eindrucksvollste aktuelle Form solcher Kommunikation, bei der ein Tänzer den Zuhörer zu erreichen sucht.

Der klassische indische Tanz gebraucht dabei nicht nur einfache Zeichen, sondern Symbole. Ein Zeichen arbeitet mit Ursache und Wirkung, entsprechend menschlicher Verständnisübereinkunft. Es verliert seinen Sinn, wenn dieser Vermittlungsprozeß abgeschlossen ist. Das Symbol aber ist Wesenselement menschlichen Seins. Wenn ich zum Beispiel ein Symbol gebrauche für den Heiligen Geist, eine Darstellung, bei der die linke Hand mit drei ausgestreckten Fingern nahe dem Herzen gehalten wird - ein Symbol der brennenden Lampe oder der wachsenden Flamme - und wenn dazu die rechte Hand in "swanbeak" gehalten wird, dann bedeutet dies Heiligkeit und Segen. Immer, wenn jemand dieses Symbol („Hasta”) im Tanz sieht, begegnet er dabei der Person des Heiligen Geistes. „Ein Symbol verbindet so vorher Getrenntes und zeigt auf etwas, das nicht gegenwärtig ist. Dem Tänzer gibt die Darstellung dieses Symbols des Heiligen Geistes das Erlebnis, ein Heiligmacher zu sein, er fühlt die Gegenwart und die Person des Heiligen Geistes in sich". Auch die Empfänger durchleben einen ähnlichen Prozeß entsprechend ihrer persönlichen Erfahrung des Heiligen Geistes und ihrer Fähigkeit, das Symbol zu erfahren („rasa”). So wird das Symbol nie ausgeschöpft und leer: es findet ein Prozeß innerer Kommunikation statt, wo wir in eine Erfahrung eintreten und uns mit dem Symbol vereinigen.

Solche Erfahrung hängt allerdings auch von unserer persönlichen Disposition ab und davon, wie weit wir fähig sind, uns der entsprechenden Kunstform zu öffnen. So ist Tanz in Wirklichkeit Kommunikation und schöpferisches Tun. Was wir dabei „kommunizieren”, wird von verschiedenen Denkern verschieden beantwortet.

Die Elemente, die eine echte Kommunikation des Tanzens und seiner Botschaft, seiner Ekstase, seines Fühlens, seiner Erfahrung und seiner Botschaft für andere durch den Tanz ermöglichen, sind im wesentlichen Raum, Zeit und menschlicher Körper. Der Tanz ist eine Darstellung im Raum wie Architektur und Malerei, er braucht aber auch die Zeit, wie etwa die Musik die Zeit und ihren Rhythmus braucht. Das Besondere aber ist, daß der Tanz eben gleichzeitig beide Sphären des Hörens und Sehens innerhalb von Raum und Zeit benutzt. Dabei ist das bedeutendste Ausdrucksmittel der menschliche Körper, der für diese Kunst geschult, den geistigen Forderungen und als Spiegel der Empfindungen verfügbar gemacht werder muß. Der Tänzer kommuniziert nicht nur seine Botschaft, er lebt sie.

Die Tatsache, daß ein Tänzer mit seinem Körper Dinge ausdrücken kann, die andere nicht artikulieren können, gibt ihm die Macht des Ausdrucks und der Kommunikation ohne das gesprochene Wort und die Kenntnis seiner Zuschauer.

Im klassischen indischen Tanz haben sich im Laufe der Zeit viele Formen entwickelt, die als Kunstformen, so wie Sprache und Bräuche, sich von Generation zu Generation vererbt haben. Dabei erscheint die Tanzsprache ausdrucksstärker als alle Sprech-Sprachen der einzelnen menschlichen Gesellschaften: sie umfaßt den ganzen Menschen und die Menschheit. 
Der Tanz besteht hauptsächlich aus drei Arten von Bewegungen: instinktiven Bewegungen, Zeichensprache und Tanzschritten. Eine Analye zeigt hier, daß der Tanz alle Unterscheidungen und Eingrenzungen zwischen Seele und Leib als getrennten Einheiten überbrückt.

Er überwindet auch alle gesellschaftlichen Unterscheidungen. Der Tänzer versucht den Mitmenschen seine Gefühle, Emotionen und inneren Erfahrungen mitzuteilen. Dies ist nicht nur gebunden an einen bestimmten Glauben, an Gesellschaft, Religion oder andere gesellschaftlichen Eingrenzungen.

So war und ist der Tanz eines der besten, wenn nicht das beste Ausdrucksmittel der Kommunikation.

In Indien ist der Tanz klar göttlichen Ursprungs: als die Welt grau und voller Sehnsucht war, baten die Menschen Brahma, den Höchsten, um eine Unterhaltung, die von allen gesehen und gehört werden könne, denn die Schriften fanden keinen Anklang bei den Massen, weil sie lehrhaft und mehrdeutig waren. Brahma, der Kenner der Wahrheit, betrachtete die vier Vedas (Schriften) und verfaßte eine fünfte, Natya Veda, die Schrift des Dramas, welche moralische und geistliche Wahrheit bot. Und, so sagte er zu den Menschen, diese Kunst ist nicht nur zu eurer Unterhaltung, sondern zeigt euch alle drei Welten. Ich habe diese Kunst entsprechend den drei Weltbewegungen geschaffen, ob in Arbeit oder Gewinn, Frieden, Freude oder Kampf, bringt sie Frucht der Gerechtigkeit für jene, die das moralische Gesetz beachten, sie begrenzt jene, die Unrecht tun. Diese Kunst ist ein Leitbild für jene, die einer Regel folgen, sie schafft den Unwissenden Weisheit, lehrt die Gelehrten ...

Eine andere Darstellung, die von den Tänzern heute gebraucht wird, beschreibt dem Tänzer jede Bewegung des Kopfes, der Augen, des Mundes, des Nackens, der Hände und des ganzen Körpers. Was ursprünglich die „Mudras” der Priester im Gebet waren, wurde unter dem Namen „hasta” eine ganze Sprache für den Tänzer.

Die zwei großen Dichtungen „Ramayana” und „Mahabharatha” sind voller Hinweise auf die religiöse Bedeutung des Tanzes. Während der buddhistischen, der Gupta, und der mittelalterlichen Geschichte Indiens spielte der Tanz eine wichtige Rolle zur spirituellen Erneuerung und Identifikation der Menschen. Die heute noch bestehenden Skulpturen, Gemälde und Bilder der Tempel sind ein beredtes Zeugnis für diese Vergangenheit. Später mit der Invasion des Islam betrachteten die Moslems es als einen Skandal, Musik und Tanz für den Gottesdienst zu gebrauchen. Als die Europäer kamen, kannten sie Tanz nur als gesellschaftliches Instrument der Unterhaltung. Mit der Entwicklung des indischen Tanzes ging es deswegen seit dem Mittelalter bergab. Erst in der Mitte des 20. Jahrhunderts entwickelte sich eine Erneuerungswelle für den klassischen indischen Tanz. Auch wenn dieser Tanz heute zu den Auditorien und auf die Bühne gelangt ist, kann er seinen religiösen Ursprung nicht verleugnen.

In Indien war es Ziel jeder Kunst, zur Vollkommenheit der spirituellen Identifikation mit dem Göttlichen zu führen. So entstanden verschiedene Kunstformen aus den Tempeln, und dabei war der Tanz die höchste Stufe des Gottesdienstes. Dieser Tanz erfüllte alle Sehnsüchte, und er entfaltete den Weg der Erlösung. Der Tänzer vermittelt seine eigenen mystischen Erfahrungen durch den Tanz. So wird der Tanz zum Ausdruck der Erlösungserfahrung und der vollen Vereinigung mit Gott; er ist nicht zuerst zweckorientiert, sondern spielt in Indien eine geistige und kulturelle Rolle.

Auch im Alten Testament war der Tanz nicht nur Teil einer weltlichen Feier, sondern auch Teil des Gottesdienstes, und im Neuen Testament gibt es auch Hinweise auf den Tanz (z.B. Matthäus 4,17 ff; Lukas 7,32). Curt Sachs zitiert in seiner „Weltgeschichte des Tanzes” einen gnostischen Hymnus aus dem 2. Jahrhundert, der offensichtlich wie viele andere solcher Werke Tänze in der christlichen Kirche begleitete. Sachs zitiert dabei auch ein angebliches Wort Jesu, das sagt: Wer nicht tanzt, kennt nicht den Weg des Lebens, und er zitiert weiter: Wer die Macht des Tanzes kennt, kennt die Macht Gottes.

Offensichtlich war der Tanz auch in den ersten christlichen Jahrhunderten Ausdrucksmittel im Gottesdienst und für den Glauben. 
Erst im Mittelalter änderte sich diese Einstellung, obwohl sich offensichtlich auch in einigen Teilen Europas wie in Spanien religiöse Tänze bis ins 20. Jahrhundert erhalten haben. Auch heute noch scheinen bei vielen gewisso Vorbehalte zu bestehen. Deswegen ist es wohl wichtig festzuhalten, daß zumindest in Indien derGlaube in vieler Hinsicht besser durch Tanz ausgedrückt werden kann als in jeder anderen Form.

Der heutige Mensch ist bestimmt von der Entwicklung der Technik, Überrationalisierung und Id eologie. Seine Sinne und sein Körper spielen eine untergeordnete Rolle im Verständnis der Realität. Dies hat nicht nur seine gesellschaftlichen und psychologischen, sondern auch seine religiösen Probleme. Es wird so schwer für diesen technisierten Menschen, Gott in seinem eigenen persönlichen und religiösen Leben zu erfahren. Diesen Zustand möchte man als mangelnde „Inkarnation” bezeichnen, unter welcher die christliche Kirche weithin leidet. Unsere Theologen, einschließlic der Liturgiker, zeigen eine große Neigung zu den Philoso. phen und Metaphysikern. Dabei haben sie fast die Verbindung mit Dichtern, Künstlern, Tänzern, Dramaturgen und Musikern verloren ...

Man hat dem Rationalismus, der Generalisierung und der Abstraktion mehr Raum geschenkt ... Die Folge dieser Entwicklung ist eine Überbetonung von Moral und Lehre im Ge. gensatz zu anderen Ausdrucksformen religiöser Erfahrung und des Glaubens. Eine Religion: die auf der Inkarnation ruht, wo das „Wort Fleisch wurde”, neigt weniger zur Philosophie und Abstraktion ...

Die Pastoralinstruktion „Communio et Progressio” hat auf die Bedeutung des künstlerischer Ausdrucks für die Kirche besonders hingewiesen (Nr. 55). Danach kann das Werk des Künstlers die tiefsten Gefühle und Erfahrungen des menschlichen Geistes erfahren und erleuch ten; es kann die geistige Wirklickeit so ausdrücken, daß sie unmittelbar erfaßt wird. Dadurck. lernt der Mensch sich selbst besser kennen, und dies ist nicht nur ein kultureller, sonderr auch ein moralischer und religiöser Gewinn.

In Indien war das Theater mit seinen künstlerischen Ausdrucksformen die älteste, aber leben digste und wirkungsvollste Form menschlichen Ausdrucks und menschlicher Kommunika tion. Auch heute noch erweckt es starke Reaktionen der Zuschauer. Es war eigentlich ein Feh ler der Kirche und ihrer Missionare, diese Kräfte der einheimischen Kommunikation wis auch den klassischen indischen Tanz nicht genügend in ihre Arbeit, den Gottesdienst und dis Verkündigung einzubeziehen.

Mehr als siebzehn Mal ist der Tanz in der Bibel erwähnt und keinmal negativ. Der Leib is nach der Schrift der Tempel Gottes, und sein Lob soll vom ganzen Menschen gesungen wer den. Der Tanz ist ein heiliges und deswegen auch ein liturgisches Zeichen. Im Tanz verkünde der Tänzer eine Botschaft für die Gemeinschaft. Im echten Tanz zeigt der Tänzer auch seinє Verbindung mit Gott und hilft seinen Zuschauern, auch an dieser Vereinigung teilzunehmen So ist sein Tanz im christlichen Kontext auch ein Ausdruck der Gemeinschaft, die in Christus lebt. So hören die Zuschauer nicht nur, sondern sie erfahren das Wort Gottes. Es besteht eir enger Zusammenhang zwischen dem Priester und dem religiösen Tänzer. Ähnlich wie de] Priester, opfert der Tänzer sich selbst und ermöglicht so den Menschen, sich auch selbst Got zu opfern und die Freude der Vereinigung mit Gott zu finden.

So kann in einem echten Tanz die Botschaft Christi wirkungsvoll verkündet und ein authentisches religiöses Erlebnis erreicht werden. Der Tanz ist eine „Kenosis”, ein Leer-Werden des Tänzers von sich, gleichzeitig aber auch eine „Koinonia”, ein Teilen mit der Gemeinschaft, ei ne wesentlich christliche Tugend.

Unlängst tanzte ich in Puri, Orissa einen neuen Tanz unter dem Thema „Etwas Wunderbares für Gott”. Nach der Vorstellung kam ein gebildeter Hindu auf die Bühne und sagte mir: Pater ich habe den Himmel und Christus auf der. Bühne gesehen. Eine andere Dame meinte: icr hätte nicht geglaubt, daß Christus und Christentum im klassischen indischen Tanz dargestell : werden können. Ähnlich schrieb eine katholische Zeitschrift. Eine andere katholische Publi. 
Unlängst tanzte ich in Puri, Orissa einen neuen Tanz unter dem Thema „Etwas Wunderbares für Gott”. Nach der Vorstellung kam ein gebildeter Hindu auf die Bühne und sagte mir: Pater, ich habe den Himmel und Christus auf der Bühne gesehen. Eine andere Dame meinte: ich hätte nicht geglaubt, daß Christus und Christentum im klassischen indischen Tanz dargestellt werden können. Ähnlich schrieb eine katholische Zeitschrift. Eine andere katholische Publikation allerdings weigerte sich, darüber zu schreiben, um die „einfachen Gläubigen” nicht zu skandalisieren.

Diese „einfachen Gläubigen” hätten allerdings einen Beitrag in englischer Sprache auch wohl nicht lesen können. Meine eigene Erfahrung zeigt mir, daß der klassische indische Tanz (Bharata Natyam) ein sehr wirkungsvolles und eindringliches Kommunikationsmittel der christlichen Verkündigung ist. Selbstverständlich muß ein solcher Tanz dann nicht nur künstlerisch gut, er muß auch fromm und Ausdruckszeichen der Erlösung sein. „Communio et Progressio" fordert, daß die heutigen Christen das Theater voll gebrauchen sollen als ein altes, aber auch neues Mittel, das oft der erste Schritt zu einer weiteren christlichen Kommunikation ist (Nr. 161). Wenn das Wort Fleisch wurde und unter uns gewohnt hat, dann sollte dies auch durch den klassischen indischen Tanz ausgedrückt werden.

\section{RÉSUMÉ}

L'auteur parle, en vertu de sa propre formation et de sa propre pratique, des valeurs chrétiennes de la danse classique indienne que l'on ressuscite de nos jours. La danse indienne classique dispose de nombreuses formes artistiques, et le langage chorégraphique se révèle plus expressif que tous les langages parlés. En Inde, la danse est d'origine divine. Son but était celui de tout art: communiquer avec Dieu jusqu'à la perfection de l'identification spirituelle. Dans l'Ancien Testament également, la danse ne faisait pas seulement partie d'une fête profane mais aussi de l'office divin. La danse est citée dans la Bible plus de 17 fois en termes positifs. Selon l'Ecriture, le corps est le temple de Dieu, et sa louange doit être chantée de l'homme tout entier. La danse est un signe saint, et par là-même, un signe liturgique également. Par l'intermédiaire de la danse, le danseur envoie un message à la communauté. Il montre son union avec Dieu et aide les spectateurs à participer à cette union. On peut ainsi proclamer grâce à la danse véritable, la Bonne Nouvelle de fạcon efficace et atteindre une véritable expérience religieuse. La danse est une "Kenosis", le danseur se vide complètement de lui-même, mais en même temps également une "Koinonia", un partage avec la communauté, une vertu essentiellement chrétienne. "Communio et Progressio" exige que les chrétiens actuels utilisent à plein le théatre - et cela inclut la danse - comme un ancien, mais également un nouveau moyen qui est souvent le premier pas vers une autre communication chrétienne ( ${ }^{\circ}{ }^{161)}$. Comme le mot chair fut et a habité parmi nous, cela devrait être également exprimé par la danse classique indienne.

\section{RESUMEN}

El autor habla, en base a su propia formación y experiencia, de los valores cristianos en la danza clásica india, redescubiertos hoy. La danza clásica india dispone de muchas formas artísticas. E1 lenguaje de la danza se manifiesta más expresivo que todos los lenguajes hablados. En India la danza tiene origen divino. Su meta es idéntica a la de todas las artes, la perfecta identificación espiritual con la divinidad. También en el Antiguo Testamento la danza es, no sólo parte de la fiesta profana, sino elemento del culto divino. Mas de 17 veces es citada la danza en la Biblia de forma positiva. El cuerpo es según la Escritura el templo de Dios. La alabanza a Dios debe ser expresada por todo el ser del hombre. La danza es un signo sagrado y por ello 
también un signo litúrgico. Muestra su vinculación con Dios y ayuda a los espectadores a participar en esa unidad. Por ello la danza puede anunciar de forma eficaz el mensaje de Cristo y llegar a ser una auténtica experiencia religiosa. La danza es una "kenosis", un vaciarse de símismo, y al mismo tiempo una "koinonia", un participar con la comunidad, una virtud esencialmente cristiana. "Communio et Progressio" propugna que los cristianos de hoy recurran plenamente al teatro - y aquí se incluye la danza - como método antiguo, pero también como nuevo método, que a menudo se convierte en el primer paso para una más amplia comunicación cristiana (Número 161). Dado que el Verbo se hizo carne y habitó entre nosotros, debería esta realidad encontrar su expresión también en la danza clásica india. 